\title{
Study on the Effective Tax Planning of Value - Added Tax under the Background of Small and Medium Enterprises Business Tax Change to Value-added Tax
}

\author{
Yanjie Ma \\ Dongfang College, Shandong University of Finance and Economics, Taian, Shandong, 271000
}

Keywords: Tax Planning, Small and Medium Enterprises, Value-added Tax

\begin{abstract}
Nowadays, the social economy is constantly developing. The share of SMEs in Chinese economy is getting bigger and bigger. At the same time, the competition among enterprises is getting fiercer and fiercer. However, small and medium-sized enterprises (SMEs) have relatively few "open-source" ways to guarantee their own business because of their weak foundations and the shortage of funds, as well as the lack of technical research. It is known that one of the most important ways for SMEs to adopt cost-saving is tax planning, which has an important influence on SMEs and is an important means to promote the sustainable development of SMEs. Based on the detailed analysis of the development status of SMEs tax planning under the background of "increasing profits and increasing taxes", this paper puts forward some strategies to improve tax planning, and hopes to provide a reference for the sustainable development of SMEs.
\end{abstract}

\section{Introduction}

Tax planning as an important part of corporate financial management, its cost-saving role is very obvious. Due to many reasons, such as subjective cognition, financial management laws and regulations, human resources, etc., the tax planning in our country can not be carried out well or the phenomenon of tax evasion in disguise can be seriously caused by the inability to correctly interpret the meaning of tax planning. Because of their limited economic strength, small and medium-sized enterprises (SMEs) reduce their costs and expenditures from tax revenue as an important guarantee for the sustainable development of SMEs. Under the conditions permitted by the relevant laws and regulations, through the rational planning of the economic activities of enterprises, the goal of financial management to reduce the actual tax burden of enterprises by means of accounting treatment is a correct understanding of tax planning. Tax planning and tax evasion are also a means of reducing the tax burden on enterprises. The fundamental difference is whether it is against the law. Tax planning Sometimes there are loopholes in the laws and regulations of the drilling phenomenon, and departure from the original intention of legislation, which to some extent reflects the laws and regulations are not perfect. "Business tax change to VAT" as the name suggests, is to change the business tax for value-added tax [1]. The most intuitive manifestation is to reduce the repeat tax payment. Enterprises in the "business tax change to VAT" under the background of a reasonable and effective tax planning, will be directly related to the tax burden on enterprises. Income tax has the characteristics of heavy tax burden, flexibility and large planning space. That is to say, the tax planning under the background of "increasing tax and increasing investment" has more space options. For small and medium-sized enterprises, tax planning will inevitably become the most effective and direct means for reducing the cost of expenditure and creating tax planning benefits.

\section{The Impact of Battalion Reform on Small and Medium Enterprises}

In October 2011, the State Council decided to carry out the work of reforming and reforming business tax and gradually changed the industry where sales tax was levied to VAT. A large number of Small and Medium Enterprises turned over the sales tax to the VAT, which was extended through battalion reform. The chain of VAT deduction could be extended through the operation of the battalion. The circulation tax system could be improved to solve the problem of double taxation, 
thereby further promoting the development of the industry and boosting the vitality of enterprises. The impact of tax policy changes mainly includes the following [2]:

Tax methods and tax content changes. Business tax and value-added tax are two different types of tax, in the calculation method business tax is based on turnover as tax basis, in accordance with the turnover and the corresponding tax rates calculated and paid business tax, which is calculated as: Tax payable $=$ turnover $\times$ tax rate. Value-added tax is divided into small-scale taxpayers and general taxpayers. Small-scale taxpayers using simple method of tax, tax payable $=$ sales $\times$ collection rate. The general taxpayers use the general tax calculation method, the tax payable is calculated as follows: Tax payable = current output tax - the current input tax, general tax method of tax payable is the current output tax deduction of current income The balance after the tax. The tax calculation method has changed after the VAT reform. At the same time, business tax and value-added tax also have different requirements in respect of tax liability occurrence time, place of tax payment, taxpayers and withholding agents, etc. After these changes, small and micro-enterprises have also changed in these aspects.

The government introduced the policy of changing the business tax to increase the government by improving the taxation administration system, reducing the burden on enterprises and stimulating the vitality of enterprises. However, the reform of the business tax involved a large number of industries such as the transportation, post and telecommunications services, service industries, cultural and sports industries. The industry that originally paid sales tax was changed to a value-added tax. As each enterprise has its own unique operating characteristics, Taxes are quite different. Tax Reform Reform business tax In reducing the overall corporate tax at the same time, some industries, some enterprises appeared tax situation worse. Business tax has different business tax rates according to different industries, while the VAT is divided into small-scale and general taxpayers. After the business tax is levied for value-added tax, the taxes and duties of small-scale taxpayers and general taxpayers all have different changes and influences. In view of this kind of situation, the enterprise's tax cost change needs to consider enterprise's own situation synthetically.

\section{3. "Tax Reform" in the Context of Tax Planning of SMEs}

We do not have a correct understanding of the concept of tax planning. The first one is that we do not recognize its initiative. Initiative is the tax evasion we take as a form of cover and then tax evasion [3]. This is obvious for the misunderstanding of tax planning, although this gain their own interests, but also undermined the interests of the state. In addition, on the basis of some related laws that we know, we can make use of the existing loopholes in the tax law and then use smart ways to reduce the tax burden. The second one is its passivity. The basic concept of tax planning is not thoroughly understood, because there is no reasonable use of the loopholes in the tax law to evade activities, so if you neglect to pay attention, you may turn tax avoidance into tax evasion In general, there is still an essential difference between tax planning and tax evasion.

Since its establishment, the company has enjoyed a good development trend and a steady increase of profits. However, compared with enterprises in the same industry, the tax burden is relatively high, the tax burden of enterprises is reasonably reduced, and the overall economic benefits and profits of enterprises are enhanced Enterprise competitiveness has become a business problem to be solved. The company's existing staff of more than 100 people, including 85 production staff, management staff of 20 people, a higher degree of automation of production. On the basis of analyzing and proving the enterprise planning space, the planning object and the feasibility of planning. According to its own characteristics, the company decided to use preferential tax policies designed and formulated in line with the actual business tax planning program. According to the Notice of the Ministry of Finance and the State Administration of Taxation on Promoting the Preferential Employment VAT Reform for Disabled Persons, the number of disabled persons resettled by the tax authorities [2016] No. 52 shall be the actual number of disabled persons resettled by the tax authorities per unit. Taxes or reduction of sales tax approach. For those resettled units and individual industrial and commercial households (hereinafter referred to as taxpayers), the number of disabled persons resettled by the tax authorities according to the taxpayers' The specific 
monthly value-added tax refundable value for each disabled person resettled by the tax authorities above the county level shall be determined according to the provincial (including autonomous regions and municipalities directly under the Central Government, Separately listed cities, the same below) 4 times the minimum monthly wage approved by the people's government. Judging whether a tax planning work is successful or not needs to be based on laws. Many SMEs in our country now have a development status quo, and most of the SMEs will actually use the relationship route to reduce the However, the tax planning work that this understanding understands is wrong. It does not essentially solve the tax burden of SMEs. We must fundamentally solve the problem. Under such circumstances, corruption will also be caused to many law enforcement officials. Many small and medium-sized enterprises that pay taxes in accordance with the law will also be deeply rooted in their grievances and there is simply no way for the enterprises to sustain their development. Therefore, we must fundamentally reverse this Wrong understanding [4].

Whether a company has the capacity of sustainable development, the most crucial point is whether the enterprise can consider the overall and local development. We need to constantly reduce the tax burden. We can not simply emphasize the problem. We need to consider the effect of the overall implementation. We need to make a more reasonable plan according to the actual situation. We need to invest funds and conduct reasonable implementation plans. At the same time, we will spend most of our time in tax planning and design, and the design costs will also be reflected in the program. In the concrete implementation of the process, we need to learn to manage the funds, and then consider the existing risk issues. We need to consider in detail and then formulate a more scientific and feasible plan. Only after careful consideration can we make plans to reduce the tax burden on enterprises. And must have the execution.

\section{Small and Medium Enterprises Tax Planning Approach and Methods}

Correct and reasonable accounting behavior is the starting point for Small and Medium Enterprises tax planning. In practical work, we must first strictly comply with the requirements of Small Enterprise Accounting Standards, standardize accounting methods and accounting system, strengthen internal control of the enterprise, set reasonable positions, Improve the management level. Second, we must improve the quality of financial staff. Different occupations of different financial staffs lead to different treatment methods for the same accounting matters. Although many different accounting methods are allowed in accordance with the tax laws, it affects the level of taxes borne by enterprises and thus affects the operating profit of the enterprises Cause different effects. Professional judgment of accounting is the overall quality of financial staff performance, accounting for different management of the business situation will have different effects. Therefore, the financial personnel of Small and Medium Enterprises should improve their accounting quality, improve their professional judgment ability and consider the relevant tax matters in an overall manner, so as to achieve the purpose of reasonable tax avoidance [5].

Small and micro enterprise financial officers should constantly update tax policy knowledge and learn about tax incentives dynamically. At present, the state has promulgated various measures to encourage the development of Small and Medium Enterprises. For example, the Ministry of Finance and the State Administration of Taxation issued a circular on further expanding the scope of the preferential policies for small and profit-making enterprises: From October 1, 2015 to December 2017 On 31st, for small profit-making enterprises with annual taxable income between 200,000 yuan and 300,000 yuan (including 300,000 yuan), the income is calculated at $50 \%$ of the taxable income and paid at the rate of $20 \%$ Income tax. According to tax concessions, Small and Medium Enterprises can fully enjoy preferential policies to achieve the purpose of reducing taxes. At the same time, Small and Medium Enterprises should fully understand the VAT preferential policies related to VAT after the VAT reform, comprehensively consider the tax costs of enterprises in the areas of preferential tax policies, the critical points of tax rates and tax incentives. In particular, we should analyze the tax costs in a number of special operating matters such as the establishment, production and management, merger and division, and debt restructuring of Small and Medium Enterprises in order to achieve the purpose of maximizing tax revenue. 


\section{Conclusions}

Small and Medium Enterprises are an important part of the market economy and have clearly supported the development of Small and Medium Enterprises from the national level. Under the background of "increasing profits and increasing profits," Small and Medium Enterprises, through understanding tax policies, earnestly formulate accounting practices that conform to the actual conditions of the Company System, raise financial planning awareness of taxpayers, to take reasonable and legal measures and methods to achieve the purpose of saving, so as to promote the further development of enterprises.

\section{References}

[1] Cheng Xiangzhi. Research on Tax Planning for Small and Medium Enterprises [J]. Market Modernization. 2015 (21):25 31.

[2] Wu Yaqin. China's science and technology Small and Medium Enterprises tax planning analysis [J]. Modern Commerce and Industry. 2013 (18) :45 48.

[3] Zeng Xi. The impact of battalion reform on Small and Medium Enterprises [J]. China Business Theory. 2016 (16) :25 31.

[4] Zhong Pingping. The Correlation between business tax Reform and Small and Medium Enterprises [J]. Journal of Finance and Economics (Academic Version). 2016 (16) :126 127.

[5] Wu Yao, Feng Dan-dan, Yi Yanan. Research on the impact of business reform on Small and Medium Enterprises [J]. Enterprise Reform and Management. 2015 (13) :99 103. 